\title{
The Public, the Private and the Power of Love: Decisive Tensions in Michiel Heyns's The Children's Day
}

\author{
Andries Wessels
}

In 1939, as Europe lay shadowed by the frightening reality of a militant Fascist totalitarianism and was about to enter a cataclysmic struggle for the survival of individual freedom, E. M. Forster published his famous essay "What I Believe," which opened with the significantly paradoxical statement: "I do not believe in Belief" (Forster 77). While, as David Medalie (38) has pointed out, Forster has often been hailed as a spokesman and defender of (the ideology of) liberal humanism, this striking opening statement in fact introduces not a defence of one ideology against another, but a scepticism towards ideology, a stand against any universalized public claim to social wisdom. Instead, Forster intimates, the individual practice of "[t]olerance, good temper and sympathy [. . .] are what really matters" (77). In 1941, as Britain girded itself with its own wartime propaganda, Forster would unapologetically reiterate (in a paper entitled "Tolerance"): "I have lost all faith in positive militant ideals; they can so seldom be carried out without thousands of human beings getting maimed or imprisoned" (57). Most controversially, Forster illustrated his point of view in "What I Believe" when he asserted: "I hate the idea of causes, and if I had to choose between betraying my country and betraying my friend, I hope I should have the guts to betray my country" (78). In this statement, which was labelled anything from extremist to unpatriotic (Medalie 42), we get an idea of what Foster proposes to shore against the ruins of public ideology, namely the notion of "personal relations," the notion that salvation should be sought in the private domain rather than the public, in private trust rather than in public posture. ${ }^{1}$ In an essay on "The Elusive Forster," introducing a

English in Africa 39 No. 1 (May 2012): 57-72

DOI: http://dx.doi.org/10.4314/eia.v39i1.3 
collection of Centenary Essays celebrating a hundred years since Forster's birth, John Beer comments that during the rise of totalitarianism in Europe, Forster discovered that the "cultivation of personal relationships, which could sometimes seem to be a form of weakness in the face of large political threats, was [...] found to nurture, in someone who took them as seriously as he did, a core of individual resistance, coupled with a welcome resilience of critical intelligence" (5).

This Forsterian opposition between the posturing of public ideology and the sanctuary of private trust is, I would suggest, central to the work of South African novelist Michiel Heyns, and provides an ethical compass particularly in his first novel, The Children's Day (2002), and in his fourth, Bodies Politic (2008).

The Children's Day is set in Verkeerdespruit, a small town in the rural Free State in the early 1960s, and at Wesley College, an English boys' private school in Bloemfontein where the protagonist, Simon, is at school in 1968. Incidents at the school, emanating from a visit by the tennis team from a Technical School in Odendaalsrus which includes Fanie van den Bergh, a boy who had attended the primary school at Verkeerdespruit with the protagonist, precipitate flashbacks to the boys' common past in Verkeerdespruit. The dominant ideology casting its shadow over this particular society is, of course, apartheid. The spirit of the time is succinctly though stridently encapsulated in an extract from a pamphlet for prospective scholars at the large bilingual Free State College, which Simon's parents initially consider for their son's secondary education:

\begin{abstract}
South Africans are increasingly becoming alienated and falling prey to international opinion and a spirit of liberalism. Discipline all too often crumbles before the onslaught of the liberal idea of freedom. A deliberate patriotic preparedness action has thus become necessary. The child must once again be taught to be proud of his country and loyal to state, church and nation. In effect, all education should be preparedness training. The child must be taught that freedom lies in the acceptance of restriction. (203-204)
\end{abstract}

The authoritarian doctrine of 'freedom in obedience' is searingly exposed in a sermon preached by a hypocritical, cheerfully paedophilic dominee and directed at the families of boys about to depart for their year of national military service, based on the story of God requiring Abraham to sacrifice Isaac: "Take now thy son, thine only son, Isaac, whom thou lovest" (Genesis 22.2). The minister concludes his reading of the tale by pointing out that the 
"love Abraham felt for his son was subordinated to his fear of God; the greater love is always marked by this fear of a higher authority" (197) - who may relent and show his love if one is unconditionally obedient. The authoritative status of the sermon is confirmed by Simon's remarking that "to criticise a sermon was to question the workings of the Lord" (198). The novel follows the percolation and effects of this prescriptive higher-moralground, narrow-minded doctrine, the very manifestation of what Forster decries in "What I Believe," in the lives of mainly marginalized individuals in the unsophisticated village of Verkeerdespruit and in the more pretentious environment of Wesley College. Heyns pitches the might of ideology, of public 'wisdom' and judgment, against the fragile value of individual loyalty.

Simon, the protagonist narrator, is a somewhat peripheral figure. He has an English father and an Afrikaans mother and is therefore regarded with suspicion in both spheres. Though his independently minded and educated parents demonstrate a healthy and subversive scepticism that sometimes stands him in good stead (bolstered by the relatively high social standing of the family in Verkeerdespruit society), he is by no means immune to the prevailing social pressures. Having read the pamphlet quoted above, Simon's mother expresses the opinion that he should go to a private school as Free State College is clearly geared to churning out "little Nationalists." Subjected to his parents' views on the one hand and those of the town on the other, Simon responds, "I don't want to be a little Nationalist, but I don't want to go to school with [. . .] Bantu children either" (204), prompting his mother's conclusive rejoinder to her husband: "You see [. . .]. He's a little Nationalist already" (204).

At Wesley College, Simon is to some extent protected by his English name, but nevertheless uncomfortably aware "of being partly one of Them" (207). "Them, alternatively They, were the Afrikaners, who were responsible for Things Being as They Are" (206). He forms an uncomfortable alliance with a German and a Jewish boy, others who do not completely fit the self-congratulatory Anglo-Saxon values of the Methodist boarding school, dubbed "Christianity, Civilisation and [perhaps ironically] Tolerance" by Simon (208). The English establishment as represented by Wesley College is revealed to be as prejudiced and judgmental as Verkeerdespruit society, merely adhering to a different set of prejudices and predispositions. Simon is surprised, for example, by the equanimity with which losses on the sports field are accepted at Wesley (whereas rugby had been treated with religious zeal and dedication in the Afrikaans community), and struggles to interpret the headmaster's comment that "Disappointing as 
the result was, it may have been in no small measure due to tactics on the part of our opponents that no Wesley boy would willingly adopt merely for the sake of winning what is after all only a game" $(211-12)$. It is translated for him by his friend Hicks as meaning "that if you're not a Wesley boy you can only win by playing dirty" (212), suggesting an attitude of inherent superiority that is ironically shown to be endemic in the so-called liberal South African English community. This is much more crudely expressed by the English-speaking, gay hair-dresser, Trevor, himself ironically a victim of marginalization, when he states that Afrikaners "looked like pigs, smelt like camels and thought like sheep" (97). The author reveals two equally ideologically driven communities in the two settings for his novel.

Heyns unfolds the confrontation between the public and the private in a series of interactions concerning the victimization of marginalized individuals by the might of public discourse. The most overtly political of these instances is the case of Mary, the black woman who works at the hairdresser's at Verkeerdespruit. As a result of the prejudices of a community informed by the public discourse of apartheid, where the women do not want their hair to be washed by a black person, Mary loses her job and is consequently "repatriated" to her homeland in the Eastern Cape, a place to which she had never been: "It transpired that Mary's homeland was a place called Elukhanyweni in Ciskei, where her mother had been born" (105). Mary has a husband and a family life in Verkeerdespruit, but no amount of common sense or compassion can save her from the apartheid state's ideological discourse which terms the distant and unknown Ciskei her home.

Crucial to Heyns's project is the role that discourse plays in the deployment of ideology. The title of the novel is taken from Robert Graves's poem, "The Cool Web," which deals with the power of language to demystify, to bring under control. The intense, even overwhelming experience of a child who faces life without the interface of definition by language is opposed in the poem to another extreme, where life is entirely negotiated by means of linguistic definition to the point where experience itself is stifled in the excessive articulation of incident: "We grow sea-green at last and coldly die/ In brininess and volubility" (qtd. in Heyns, Children's Day 5). Articulation in language is seen to overtake and overwhelm the immediacy of actual experience, of lived reality. ${ }^{2}$ In the novel, this phenomenon is first suggested in the horror of the children's response to Fanie van den Bergh's epileptic fit in the standard two class, which is abruptly assuaged when the teacher announces that what Fanie is suffering is a fit: "The information calmed us immediately. We'd heard of fits. The horrible visitation had been named, explained, tamed in our minds" (18). 
The experience is contained by its mediation through language. Ideological language, Heyns further suggests in the novel, is particularly apt not only at negotiating, but distorting lived reality. Simon's father explains this to him with reference to the Sabotage Act that had been passed the previous year. Stating that "it's all a matter of definition" (88), his father elaborates:

'Well then, sabotage used to mean planting a bomb and blowing up something; but the Sabotage Act now defines sabotage in such a way that it can mean, well, lots of things.'

'Anything that the government regards as a threat to itself,' my mother interjected.

[...] 'So sabotage is now [...] a matter of definition.'

'And who makes the definitions?'

'The people in charge, the people who make the laws.'

This clearly bears upon the definition of a place that Mary had never been to as her "homeland," and the point is brought home to Simon when it is later rumoured that Verkeerdespruit itself might be re-designated as a "Bantustan." He has to consider "the processes whereby Verkeerdespruit was to be the Traditional Homeland of thousands of people who had never seen it, whereas we who had grown up in it would be foreigners in our own village" (131-32). Public language is set in opposition to private experience; public brutality is masked by official terminology, but this does not soften the experience of the victimized individual; it serves on the contrary to highlight the distinction between ideological violence and personal experience.

In his essay "Politics and the English Language" (1946), George Orwell makes a similar point, namely that in "our time broadly speaking, political writing is bad writing," that political speech and writing generally consist of "the defense of the indefensible," that government brutality is glossed over by official jargon, so that instead of saying "I believe in killing off your opponents when you can get good results by doing so," the official spokesman of authority would euphemistically declare instead:

While freely conceding that the Soviet regime exhibits certain features which the humanitarian may be inclined to deplore, we must, I think, agree that a certain curtailment of the right to political opposition is an unavoidable concomitant of transitional periods, and that the rigours which the Russian people have been called upon to undergo have been amply justified in the sphere of concrete achievement. 
This is a perfect instance of what Simon's father would call "a matter of definition" (Heyns 88).

The language of power not only distorts the reality of experience with regard to political concepts such as "sabotage" or "genocide," but also invades the private, domestic life of people in an ideologically driven society, shaping the thinking of the young and their ability to conceptualize. When Simon protests against the term "kaffir" when his school friend, Louis, calls Simon's dog (which he had bought from an African man) a "kaffir dog," Louis replies

'Kaffir dog, native dog, Bantu dog, same difference,' he said. 'My father says there are too many of them and they don't have licences.'

'Dumbo has a licence, so he's not a ... native dog.'

'He's a kaffir dog with a licence, that's all,' he taunted. 'It's like ... like a kaffir with a driving licence. He's still a kaffir isn't he?'

This logic seemed wrong to me, even in a country that I was starting to realise had its own rules of classification.

It is Simon's final rejoinder, "As long as he's my dog it doesn't matter what anybody calls him" (164), that clearly exposes the chasm between the public symbolic discourse of power and private experience.

In his book, Language and Symbolic Power (1991), French linguist Pierre Bourdieu suggests that language "represents [. . .] authority, manifests and symbolizes it" (109). Thus, linguistic exchanges reflect the power relations between speakers or the groups they represent (37). According to Bourdieu power is seldom exercised in bald, physical terms and is more often transmuted into symbolic form. One such transmutation is "official language," the language of authority, which he describes as "authorized, authoritative language, speech that is accredited, [. . .] performative, claiming (with the greatest chance of success) to be effective" (69-70). Such speech gains authority not from the individual identity of a speaker, but because "his reality [. . .] is based not on his personal conviction or pretension [. . .] but rather on the collective belief, guaranteed by the institution" (125-26). In this way the language of the ideology of apartheid is demonstrated in The Children's Day as holding sway over public imagination and conceptualization, but distorting or disregarding individual experiential reality. Although Louis is only a child who speaks very crudely and not an officer of the government, his speech is nevertheless invested 
with the authority that is rooted in "the collective belief, guaranteed by the institution" (Bourdieu 126) of the apartheid state. This aspect is further illustrated by the clash between public authority and personal experience signalled by the advent of another marginalized individual, the "ducktail" Steve, in the small town of Verkeerdespruit.

Steve arrives in Verkeerdespruit, ostensibly from Johannesburg (actually from Welkom), on a gleaming Matchless G9 motorcycle like "a creature of another essence, too marvellous to correspond to any of our categories of fear" (27). Admired by the little boys, all the more so because of the censure of the adult community which endows him with "the added allure of illegitimacy" (28), Steve is a marginal figure who does not conform to the rules determined by the Verkeerdespruit authorities. He takes Simon for a naked swim in the Modder River, revealing to him (in a scene strongly reminiscent of the interaction between the boy Leo and the farmer Ted Burgess in L. P. Hartley's The Go-Between [1953]) $)^{3}$ the full glory of the adult male body for the first time - to the dismay of Simon's mother and the abject horror of Mrs Opperman, Verkeerdespruit's principal moral custodian, who hisses "Pervert!" at Steve when she and Simon's mother pitch up at the swimming hole to "rescue" Simon. Steve befriends other marginalized figures, like the unattractive but astute "Betty the Exchange" and Fanie van den Bergh, Simon's impoverished and dull classmate. While Steve is ultimately exposed as no all-round hero - his private life is singularly messy - he does reveal a heroic side in terms of the novel's theme of the public versus the private. When Simon's classmate Louis states (with regard to Steve's supposed Johannesburg provenance, a city associated in Verkeerdespruit with the threat of communism), "[m]y father says the Communists want to take over the country and give it to the kaffirs" (31), Steve responds with a shrug: "They don't bother me, long as they leave me alone." Steve personifies the freedom of the private individual to lead his life on his own terms in the face of Bourdieu's "authoritative language," in the face of ideology, of the "collective belief, guaranteed by the institution" (Bourdieu 69-70), in this case the apartheid state. Simon responds instinctively to Steve's outlook without being able to articulate a justification for his unorthodox approach: "Though I was by no means so emancipated from my class and time as to feel anything but horror for Umkhonto we Sizwe, Steve's cavalier indifference to their dire plots struck me as very fine" (31).

Steve's position as an outsider not conforming to the tribe's customs is soon linked by the community to the political situation in the country; during a period of intense demonization of the young man, Annette Loubser 
declares that "she had seen Steve talk to two Bantus next to the road" (48) as further evidence of his moral turpitude. Steve's uniform of jeans and a tight t-shirt is moreover dubbed "Tsotsi clothes" (26), again to discredit him and to identify him with the socially and politically marginalized in Verkeerdespruit.

When Steve disappears from Verkeerdespruit with his young friend Fanie for a while, the hysterical moral custodians eventually trace him to his parents' house in Winburg. There he is arrested for abducting Fanie, who clearly went with him of his own accord and whose mother is quite unperturbed by the excursion. Steve is eventually convicted and sentenced to three years in prison, even though the magistrate concedes that the accused had apparently "not interfered" with the boy (52). The fact that Steve is perceived to have kissed Fanie once, is used as evidence against him. When Simon, unknowingly jealous with respect to the attentions of his friend, Steve, interrogates Fanie on why Steve kissed him, Fanie smiles radiantly and declares "[b]ecause he liked me" (53). A few months later The Friend reports the death in prison of Steve, "[t]he convicted child molester" (53), murdered by his cell-mate. Heyns uses the unprejudiced eye of the child trope to expose the horror of Steve's fate: "'So, Steve was killed because he kissed Fanie?' I pursued. My father thought for a moment, then shrugged slightly and said 'Yes, I suppose that's what it amounts to"' (54).

Heyns intensifies the irony of this conclusion by contrasting Simon's experience of having his jaw broken by a brutal primary school teacher, who is then protected by the system and sent to teach elsewhere (in black schools, in fact), with that of Steve, who is killed because of kissing Fanie. On finding that Mr de Wet will not be prosecuted in a court of law, Simon asks his father, "Why is it molesting for Steve to kiss Fanie but not for Mr de Wet to break my jaw?" (87), and Simon's father replies that "it's all a matter of definition, don't you see?" (88), evoking Bourdieu's language of authority. The community protects its own authority and "collective belief," and apostates are not tolerated.

Steve's messy marital life is exposed in the press after the trial and Betty of the Exchange, with whom Steve had spent an illicit week-end at the Mazelspoort resort near Bloemfontein, reveals to Simon that Steve had pocketed her savings with which the two of them were supposed to move to Cape Town. Nevertheless, in the memories of those other marginalized souls with whom Steve associated - Simon, Betty the Exchange and Fanie - Steve remains a champion and symbol of private loyalty, of personal allegiance in the face of public censure. Betty the Exchange tells Simon that she did not want Steve to go to jail, because she loved him in spite of his stealing from 
her, adding "slowly and deliberately, "And I still love him. I love Steve"” (70). Betty's declaration echoes E. M. Forster's assertion in "What I Believe" that "What is good in people - and consequently in the world is [. . . their belief in friendship and loyalty for their own sakes" (81), "something comparatively solid in a world full of violence and cruelty" (77).

The theme of homosexuality is delicately woven into the plot, but proves crucial for the conclusion. Initially there is no indication that Simon might be gay and he certainly has no such awareness. Indeed, he has a serious crush on his classmate, Juliana Swanepoel, in Standard 4. In an interview with Francois Smith (2003), Michiel Heyns explains that Simon's hybrid Afrikaans/English identity is intended to suggest marginalization, not belonging anywhere exactly. When asked if this is autobiographical, Heyns responds that he was in fact Afrikaans on both sides of his family and that his marginalization had more to do with reading a lot from an early age (like Simon), which brought about a distance between him and his friends. $\mathrm{He}$ then adds significantly, "Eventually you also discover that you are gay and you become a marginal figure once again. I made all of that part of the book" (Smith 6) ${ }^{4}$ By the way its alternative culture is perceived by dominant society, "the love that dares not speak its name" places gay people at a disjuncture from the authoritative voice of publicly endorsed morality. Bourdieu talks about a person's habitus, a group of qualities and characteristics that determine the way a person behaves and thinks, defining what he or she considers appropriate and inappropriate behaviour. He significantly suggests that the habitus is sociologically determined, "unquestionably the product of social determinisms" (Bourdieu 51). Society shapes the norms of individuals, and those whose identity violates the norms that that particular society has adopted as "appropriate," are by definition outsiders, out of step with the official, public discourse of that society. It is perhaps logical that such people would find their moral guidance not in the voice of public morality, but rather in personal trust, in private loyalty. ${ }^{5}$

The homosexual theme in The Children's Day is overtly introduced by the arrival in Verkeerdespruit of Trevor, the gay hair-dresser. He is labelled by his manner and his dress as an outsider and immediately becomes part of the group of marginalized individuals that meet in the café: Betty the Exchange, Simon, Fanie. His outsider status is confirmed by the fact that the town's policeman promptly phones the Bloemfontein police to ask if there is perhaps any criminal charge against Trevor, only and sadly to find that they have never heard of him. There is an assumption of anti-social behaviour, of criminality even, based purely on Trevor's sexual orientation, on his difference. 
Trevor is brought to Verkeerdespruit by Klasie Vermaak, the perfectionist postmaster, who is a deacon in the church and who lives with his conservative, overbearing, eternally mourning mother. Klasie manages to get Trevor, who had been beaten up by gay-bashers when he found him on the side of the road, into his mother's house by evoking the parable of the Good Samaritan. The town is agog but for a time all is well: Klasie is happy for the first time in his life, Trevor builds up a big following as a hair-stylist and even Mrs Vermaak lightens up, exchanging her dour black dresses for concoctions in turquoise chiffon under Trevor's guidance. However, the guardians of public morality cannot countenance such subversion of their sway, and soon step in to put an end to the personal happiness of all concerned. Mrs Opperman decides that the "devil had come to Verkeerdespruit to tempt Mrs Vermaak and that she had sold her soul for a turquoise dress" (103). The dominee first speaks to Klasie, causing him to resign the deaconship, though he remains bravely unapologetic about his love for Trevor. Not content with this result, the dominee then speaks to Mrs Vermaak, explaining to her that her son is a sodomite and will bring the Lord's vengeance to bear upon their household. When Trevor, to calm the hysteria that follows, tells Mrs Vermaak, who also seems to be in love with him, that he loves Klasie "as a brother" (116), Klasie takes offence and dumps Trevor at the side of the road as he found him, precipitating the departure of that bird of paradise from drab Verkeerdespruit. It is mentioned casually later in the novel that Klasie has committed suicide. Once again public morality, the authoritative language of collective belief or ideology, carries the day, to the detriment of individual happiness and fulfilment.

It is Trevor who first subtly suggests that Simon might be gay, although Simon does not understand the implication when Trevor states with regard to Mary's "repatriation:" "When you get older you'll realise that people like me and I wouldn't wonder you too are just as oppressed by [the Afrikaners'] laws as Mary" (106). Simon's reaction to Steve's adult body at the swimming hole and his jealousy of Steve's friendship with Fanie are further clues, culminating in his adventure with the paedophilic dominee at Bleshoenderbaai - which introduces him to sex, but fills him with anxiety and guilt. When Simon chances upon his friend, the senior boy Hicks, engaging in mutual masturbation with another boy in the chapel at Wesley College, it is also, unbeknownst to Simon himself, his jealousy concerning his friend Hicks that drives him to the Headmaster to insist on this act being severely punished. The Rev. Robinson, Headmaster of Wesley College, turns out to be a profoundly moral man, however, and refuses to acquiesce to Simon's demands. Once he has determined the relatively inoffensive nature 
of the misdemeanour in a hilariously funny scene, he tries to show the boy the potential destructiveness of his insistence upon public revelation and punishment. When Simon remains obdurate, he frightens him into agreeing not to reveal anything concerning the incident by threatening him with never-ending, subtle, unobtrusive punishment. The Rev. Robinson has no truck with the public facade of self-congratulatory morality and is only concerned about the individual well-being of the boys concerned, including Simon. His final comment ties Simon's attitude, his lovelessness, to the political situation in South Africa and evokes Forster's controversial statement about betraying your country or your friend: "If a boy of 13 is prepared to betray his friends just because he has the power to do so, is it any wonder that things are the way they are out there?" (231).

This is in a way the crux of the novel, linked as it is to the ideas expressed by Forster in "What I Believe." David Medalie points out that one of the "recurring questions in Forster's fiction, most notably in Howards End and A Passage to India, is whether love, especially as expressed in the 'personal relations' doctrine, may be converted into a socially dynamic force" (Medalie 40). Forster articulates his thoughts on this score and suggests a link between love and politics in an essay called "The Menace to Freedom" (1935):

However, Man has another wish, besides the wish to be free, and that is the wish to love, and perhaps something may be born form the union of the two [. . .]. Love, after a dreadful period of inflation, is perhaps coming back to its proper level and may steady civilisation [. . .]. The desire to devote oneself to another person or persons seems to be as innate as the desire for personal liberty. If the two desires could combine, the menace to freedom from within, the fundamental menace, might disappear, and the political evils now filling all the foreground of our lives would be deprived of the poison that nourishes them.

(Forster 22-23)

Medalie comments that

the advent of a crisis of vast proportions makes it easier for [Forster] than it was before to elevate 'personal relations' and 'love' [. . .] to a position where social freedom is predicated upon them; and, inversely and perhaps more controversially, to suggest that all socio-political questions and solutions be recast in terms of love, the individual and relations between individuals. 
This seems to be exactly what the Headmaster of Wesley College in The Children's Day has in mind, when he tells an uncomprehending Simon: "The reason for Things Being as they Are is seldom deliberate evil - it is lovelessness" (232). Like Forster, he suggests that the solution to political injustice cannot be found in grand ideological schemes, but only in the exercise of personal relations, by a disposition of love and loyalty between individual human beings.

When the Headmaster asks Simon whether he has learnt from the incident, his answer comically illustrates that he has not at all understood the profound nature of what the Reverend Robinson has tried to impart to him. The trajectory of Simon's finally achieving this insight has to follow his own experience, his "personal relations" with his schoolmate, Fanie van den Bergh.

The relationship between Simon and his counterpart, Fanie, is central to the novel. The fact that the whole Children's Day memoir is precipitated by Simon's re-encountering Fanie at Wesley College in December 1968, confirms the organic centrality of the relationship to the novel: the book in fact consists of memories generated by Simon and Fanie's interaction on the day of the fateful tennis match (Britz 19). Simon is the precocious, privileged son of the Verkeerdespruit magistrate, whereas Fanie is the dull, neglected son of the local barman who needs help with his reading. Fanie remains to an extent an enigmatic character, seemingly unattractive, apparently dull, dismissed by Simon as "just ordinary" (12), yet sometimes surprising Simon and the reader with an astute observation, a humble, docile, unquestioning, accepting understanding of human behaviour. "Fanie knows more than you think," (28) Steve tells Simon. He has a "general air of being lost but not minding" (24), but is also equipped with a rare, sudden, and utterly transforming smile.

That there is a special relationship between Simon and Fanie is suggested early on in the novel, although Simon remains consistently unaware of this. When asked by the principal what was responsible for his epileptic fit in the school bathrooms, Fanie's eyes wander over the crowd until they meet Simon's. "'It was him,' he said triumphantly, pointing at me. 'He gave me a fright"" (23). Simon is bewildered by this accusation and equally astonished when Juliana Swanepoel puts him up to ask Fanie to change places in the classroom, because "He'll do anything you ask him" (127). Yet Fanie makes no nuisance of himself, quietly watching Simon's tennis matches with the teacher, Mr van der Walt, an action that Simon ascribes (possibly correctly) to Fanie's adoration of the teacher. Simon is deeply embarrassed by Fanie's appearance as part of the Technical School tennis team to play in a 
tournament against Wesley College, as the "Clutch Plate" (what the Wesley boys call the Technical school boys) latches on to him and lays claim to him because of their prior acquaintance. Questioned by his roommate on the relationship and the fact that Fanie seems to find Simon good company, Simon admits, "[h]e seems to, though heaven knows why. It's not as if I've ever given him much to like me for" (235). Worse yet is that Fanie manages to beat him in the deciding match of the tournament, when Simon is so distracted by the movement of Fanie's private parts under the inadequate tennis shorts provided by the OVV (which gives rise to gales of laughter among the Wesley boys) that he cannot concentrate on his game. When Fanie finally embarrasses Simon with his idiosyncratic and unsophisticated interpretation of the plot of The Sound of Music, screened by the school that night, to the great amusement of the boys sitting next to them, Simon rushes out of the hall into the stormy night, inevitably followed by his faithful adherent, preparing the ground for the dramatic finale of the novel, a conclusion that Cecile Cilliers calls "a remarkable, poignant resolution, which, more than solution, is rather summary and interwovenness" (Cilliers 6). ${ }^{6}$

Outside, Fanie tries to placate a furious Simon by assuring him that he need not feel sorry for him (he assumes that Simon has deliberately lost their match because of his pity for Fanie). He moreover reveals that when the police came to fetch Steve, he had said that he hated Simon for telling the police where to find them. But Steve had told him not to hate Simon, because Simon liked him and would look after him once Steve was gone. An outraged Simon splutters that he does not feel sorry for Fanie, dislikes him and has only ever considered him a nuisance, but Fanie responds implacably that Steve had told him that Simon did not know that he liked him. Simon finally calls Fanie a "Clutch Plate pervert" and pushes him out of his way. Then, suddenly perceiving him to be "completely vulnerable and very beautiful" in the flashes of lightning, he strikes him down.

In the course of the novel both epileptic fits and biting are associated with sensuality, eroticism, intimacy and love. Not possessing a sexual vocabulary, Simon can only say that "Mr Viljoen was having a fit" (155) when asked to describe the scene where he finds the principal in flagrante delicto with a young teacher. When Simon is woken at night by the shot that kills his beloved dog due to an (unfounded) suspicion of rabies (an official police action), he rushes out and puts his hand in the dying dog's bleeding, panting mouth (174-75). He compares his own first exposure to sexuality with the paedophilic dominee to a fit and also bites the tongue of the dominee so that he bleeds profusely. These scenes prepare the way for the 
climactic conclusion to the novel. Seeing that Fanie is bleeding, Simon rushes to his side, trying to apologize. But he witnesses Fanie going into a fit:

\begin{abstract}
I knelt by him. I remembered that I had to turn him on his side, but I was entranced by the rhythmic convulsion so impartially suggestive of an extremity of pleasure and a torment of pain, the blind face in its transport of oblivion; the frail body punishing itself in its fierce assault upon the earth, the image of love under the spell of the passion it cannot tame nor deny nor even articulate. And as I knelt over Fanie van den Bergh, the rain came. In the wind and the rain and the wide glare of the sky, I was enclosed, alone with Fanie. I put my hand over his mouth, wet with spittle and blood and rain, and I searched for the separation of his clenched lips, forced open the contracting mouth, felt for a moment the mutely writhing tongue, and waited for the agony of the jaws closing possessively around my fingers in dumb absolution.
\end{abstract}

Etienne Britz comments that "God speaks in the Free State thunder that rumbles and flashes above their heads in this concluding scene" (21). ${ }^{7}$ By his final actions, Simon endorses the paramountcy of "personal relations," accepts the personal bonds between himself and Fanie, and acknowledges his own marginal identity in the face of public morality and judgment. In his personal penance, Simon discovers that love and private loyalty and faith will creep where 'appropriate' public opinion cannot walk. In The Children's Day, Michiel Heyns indicates that salvation for the individual is not to be found in the proclamations of a public morality that expresses "the collective belief, guaranteed by the institution" (Bourdieu 126) of society, but can only be sought, elusive as it will be, in private faith, in personal fidelity, in what Forster called, after Swinburne, "Love, the Beloved Republic" (79).

\title{
NOTES
}

1. While Forster, influenced by G. E. Moore's notions on life and art, always affirmed the value of 'personal relations' he had been suspicious of sweeping claims being made on behalf of this 'doctrine' against the background of the sense of fragmentation that characterized the Modernist experience, and warned in 'A Note on the Way' (1934): 'Art is not enough, any more than love is enough.' However, the rise of the totalitarian regimes in Europe caused him to pin more of his hopes on this notion as the value of human life was being progressively undermined in the totalitarian states (see Medalie 36-37). 
2. Using the young and relatively innocent Simon as the narrator of the novel capitalizes on the notion of the unspoilt, fresh and true eye of the child, of experience unmediated by a jaundiced linguistic sophistication. This is clearly related to the well-established satirical literary trope, popular in the eighteenth century, of the ingénu, the uninitiated outsider who brings a fresh perspective on the familiar by his unspoilt perspective, in for example Montesquieu's Lettres Persanes [1721], Voltaire's Candide [1759] and L'Ingénu [1767] and Goldsmith's The Citizen of the World [1760].

3. As Leo, in The Go-Between, watches Ted Burgess swimming in the river he senses the natural power and sensuality of the farmer's body without understanding it: "I retreated almost in fear before that powerful body, which spoke to me of something I did not know" (56); but he is nevertheless attracted to it: "and I wondered, what it must feel like to be him, master of those limbs which have passed beyond the need of gym and playing field, and exist for their own strength and beauty?" (57). After swimming with Steve in the river, Simon admires Steve's body in a similar way:

Then he got up from the ledge and stretched himself in the sun. I had never seen a grown man without clothes before and I looked at the hair on his body and wondered why men got hair there, and what it felt like. I put out my hand and touched the hair on his chest. It was rougher than ordinary hair.

Steve said, 'You'll have some of that too one day. Plenty of time.' But I looked at Steve's body, the broad shoulders and thick arms, the strong legs, and shook my head. I knew that my body would never look like that. (37)

4. Own translation. The original reads: "Eindelik kom jy ook agter jy is gay en weer word jy 'n randfiguur. Ek maak dit toe alles deel van die boek."

5. It is notable that the author of The Children's Day, Michiel Heyns, and the author of "What I Believe," E. M. Forster, both of whom take a stand against public morality in favour of personal relations and personal faith, are indeed both gay men.

6. Own translation. The original reads: "'n merkwaardige, ontroerende ontknoping, wat, meer as oplossing, eerder opsomming en verweefdheid is."

7. Own translation. The original reads: "God spreek binne dié slottoneel mee in die Vrystaatse donnerweer wat bokant hulle koppe rommel en flits."

\section{WORKS CITED}

Beer, John. "The Elusive Forster." Introduction. E. M. Forster: A Human Exploration - Centenary Essays. Ed. G. K. Das and John Beer. London: Macmillan, 1979. 1-10.

Bourdieu, Pierre. Language and Symbolic Power. Ed. J. B. Thompson. Trans. G. Raymond and M. Adamson. Cambridge: Polity Press, 1991.

Britz, Etienne. "Handleiding vir Insig boekklub: Michiel Heyns, Verkeerdespruit." 2007.

$<$ http://afrikaansresensies.wikispaces.com/file/view/ verkeerdespruit handleiding.pdf $>$

Cilliers, Cecile. "Deernisvolle debuut merkwaardig." Rev. of The Children's Day, by Michiel Heyns. Die Volksblad, 17 February 2003: 6. 


\section{ANDRIES WESSELS}

Forster, E. M. Two Cheers for Democracy. London: Edward Arnold, 1951.

Hartley, L. P. The Go-Between. 1953. London: Penguin, 1987.

Heyns, Michiel. The Children’s Day. Jeppestown: Jonathan Ball, 2002.

. Bodies Politic. Jeppestown: Jonathan Ball, 2008.

Medalie, David. "Bloomsbury and Other Values." The Cambridge Companion to E. M. Forster. Ed. David Bradshaw. Cambridge: Cambridge UP, 2007. $32-46$.

Orwell, George. "Politics and the English Language." Inside the Whale and Other Essays. 1949. <http://www.mtholyoke.edu/acad/intrel/orwell46.htm>

Smith, Francois. "VS-kindertyd grondslag vir debuut: Heyns se skryfwerk toon ooreenkomste met J. M. Coetzee." Interview with Michiel Heyns. Die Volksblad, 3 February 2003: 6. 